\title{
Spatial Evolution of the European Container Ports' System in Perspective of the Location Theory
}

\author{
Karolina A. Krośnicka ${ }^{1 *}$ \\ ${ }^{1}$ Department of Urban Design and Regional Planning, Faculty of Architecture, Gdańsk University of \\ Technology, Narutowicza Street 11/12, 80-233 Gdańsk, Poland
}

\begin{abstract}
The maritime container terminal is no longer a spatially coherent object. Functionally it ends, where their most external components are located. The process of location splitting of container terminals (ger. Standortspaltung) can be treated as next stage of their discrete growth. The new container facilities are being built to improve the containers' flow, passing from port terminals to cities situated in their hinterland and vice versa. The external components of container terminals have a very diverse program, are functionally complex, and due to advanced technologies of information and logistics they are interconnected into one system. The structure of the functional bindings of a maritime container terminal could be compared to the dendritic shape of a neuron, the kernel of which is a terminal, and the arms are transportation corridors ended with distant land intermodal terminals. The physical feature of this system is the logistics landscape with vast areas and large cubature. The aim of the paper is to present the graphical model explaining the changes in distribution and hierarchy of container terminals' external elements in relation to the network of cities and transportation.
\end{abstract}

\section{Evolution of the container system}

The UNCTAD report [1 p. 4], same as the work of Rodrigue, Comtois and Slack [2], distinguishes three phases of the evolution of the container system. These are in turn: containerization of the maritime transport system, containerization of the land transport system and the development phase of intermodal operations. This paper [see also: 3] proposes adding to the mentioned phases the fourth one: the phase of integration of the container system. These stages are clearly reflected in changes of the spatial structure of the container system. Although they do not have sharp chronological boundaries, they can nevertheless be given a contractual time frame. The next phases of the spatial evolution of the container system are described below and are shown in Figure 1.

The stage of development of the maritime container subsystem (1956-1970) is the period of crystallization of the maritime network. Land transport connections of container terminals were based mainly on the existing general cargo distribution system. In this phase the first terminals serving containers were erected. Their appearance shaped the later course

\footnotetext{
${ }^{*}$ Corresponding author: karkrosn@pg.edu.pl
} 
of shipping routes. In the initial period, the implementation of innovative container infrastructure entailed an increase in the cost of shipping companies, as the port authorities fearing the lack of investment depreciation, passed on the cost of adapting quays for shipowners $[4$, pp. 7,136$]$.

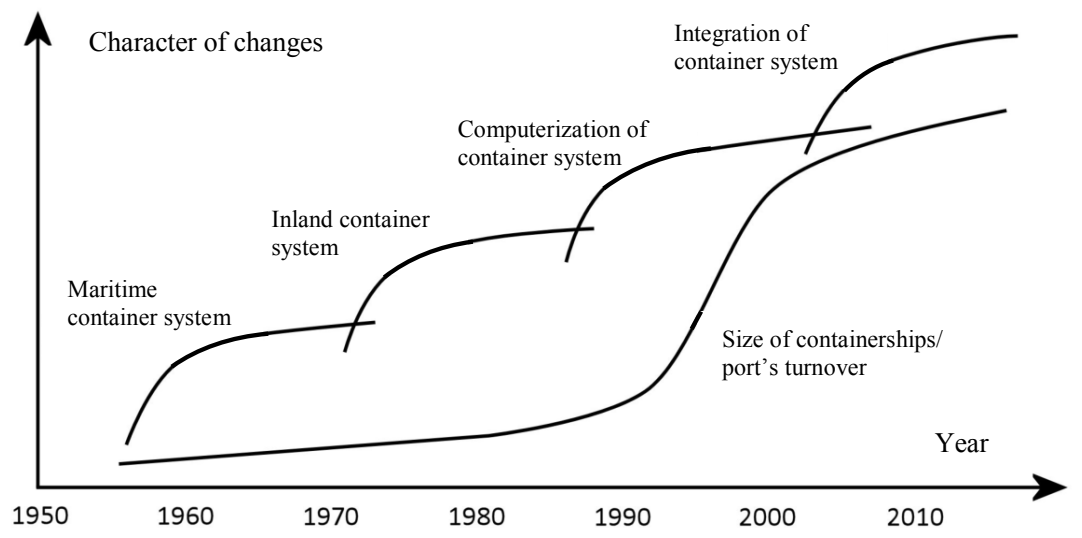

Fig. 1. Stages of the world's container system development [3, p. 69].

In the phase of development of the inland container subsystem (1970-1985/1988) a division into main container ports and feeder ports took place. Transport corridors running from the main container ports inlands have developed and transport connections parallel to the shoreline appeared. In the area directly adjacent to container terminals (up to $5 \mathrm{~km}$ ), in vicinity of large inland cities, and in the transportation nodes (usually situated about 300 $\mathrm{km}$ from sea terminals) the new logistic objects, functionally connected with container terminals, have been created. In this phase the development of intermodal operations and the containerization of the inland transport system took place $(1970 \mathrm{~s}$ - the end of the 1980s). This stage consisted in improving the efficiency of the land-based container system, as well as in compacting the transport and logistics connections (highways) and in the development of regional inland transport hubs. In many cases, the organization of the land transport chain was taken over by ship-owners. This phenomenon Krasucki and Neider [4, p. 136] described as "the descent of ship-owners to land". As the route of the load could be organized using a single transport document, it became possible to introduce combined container transports. Containerization has forced the railway network to adapt to the operation of heavier trains, with a higher frequency of commodity trains. A new type of commodity railway stations operating at the interface of at least two modes of transport, also emerged - inland railway container terminals were created (intermodal terminals). In the 1980s the differentiation between container hubs and feeder ports has deepened, and the gradual transformation of the global shipping routes took place.

In the third phase of development (1985/1988 - 2001/2003), sometimes referred as the "logistics platform of trade", the container system was computerized. An integrated electronic data transmission system has started to develop, which has allowed port services to extend beyond the immediate port borders. The result of the development of port info-structure strengthened the links between the port and ports' users, as well as between the port and the port city. Container transport has proliferated. At the same time, the phenomena of main-porting (development of hub ports) and of multi-porting (development of many small feeder ports) occurred. In the foreland of some container hubs gate-way terminals started to be created. Deepwater container terminals of the off-shore type have appeared in most of ports [5]. At the ports' hinterland the multimodal door-to- 
door transport and inland terminals have developed. Some of the functions were derived from the terminals into the urban area of the port city (up to $50 \mathrm{~km}$ ). Inland transport corridors extended perpendicularly to the shore (over $300 \mathrm{~km}$ ), and the second-line logistic connections appeared. In the area of further hinterland (150-300 km) a network of logistics centers has been developed. The development of the logistics system has led to the expansion and overlapping of hinterlands of larger container ports.

According to $\mathrm{Lu}$ and Chang [6, p. 155] at the beginning of the 21 st century the container system entered the fourth phase of development (2001/2003-). For this phase according to Monios [7, p. 37] two parallel tendencies are characteristic: enlargement of port facilities by creating inland terminals integrated with the maritime ones (port regionalization), and integration of logistics chains. At the same time, following the concept of Robinson [8] and Woo et al. [9] that the port has now lost its monopoly position and has become a place of dynamically changing logistic links. So far, seaports competed with each other mainly in terms of the scale of transport, quality of services, diversification of activities and prices for services. At present, it is not ports that compete with each other - it is integrated logistics supply chains, in which ports are only one of the components, and not any more an independent transport node [10, pp. 155, 157, 168]. The fourth phase of the container system development consists in the possibility of providing transport services within the whole available land connection network and various loading and unloading ports, using various means of land transport. Therefore, now the transition from the model of "determined supply chain" to "flexible road selection" (synchro-modal transport) take place. This concept is, among other things, the result of treating the supply chain as a warehouse space (the concept of traveling warehouse) and possibility of taking decisions on the means of transport on an ongoing basis during the transport process [11, p. 570]. For this reason, the management of seaports in various ways supports and coordinates the creation of investments in their hinterlands, developing and strengthening the functioning of transport corridors and logistics supply chains, including inland transshipment terminals, logistics centers and dry ports. During the integration of the container system, in addition to strengthening the previously mentioned trends, the construction of automated deep-water terminals and dry ports took place, both in the zone of the inactive port city region (at a distance of 50 to $150 \mathrm{~km}$ from the terminal) and in the zone above $300 \mathrm{~km}$ from the terminal. The transport corridors of the hinterland were also extended and reoriented. The networking of transport and popularization of synchro-modal transport took place. In China the phenomenon of clustering dry ports was observed [6] . Notteboom and Rodrigue [12, p. 303 ] also noted, that the inland terminal may now be an island formation in the hinterland of another container port, intercepting the cargo in favor of its "own" port. Thus the port's hinterland may be discontinuous. According to Notteboom and Rodrigue [12, p. 306] local and national authorities are increasingly interfering in the process of shaping the logistics network trying to regulate the location of individual logistic facilities, including through fiscal incentives. Roso and others [13], relying on Swedish experience, believe that dry ports are a manifestation of a conscious strategy of port or regional authorities. Other authors however suggest, that the process of regionalization is imposed on ports by external forces, and that so far these activities are not coordinated enough to be considered as strategic management of the logistic network in the region or country [14, p. 41], [12, p. 307].

The trends that currently appear, which may be the next phase of containerization, are the automation of sea and land transport (automatic vesels and cars) and blockchain technology (the so-called dispersed register). The tests using blockchain technology have already been carried out by the port of Antwerp, Rotterdam and by Møller - Mærsk. 


\section{Model of spatial evolution of the container system in terms of location theory}

The paper presents a model of the evolution of the Europe container system in terms of the location theory, taking into account in particular the development of Polish container ports (Fig. 1.). In Europe, changes within the container system were different than in Asia or North America. In Europe, for historical reasons, a regular network of large cities (as for a European scale) is complemented by a dense network of small and medium-sized cities, which results in a more even distribution of transport corridors at the port cities' hinterlands. In Asia, large cities are concentrated in the coastal zone, hence port cities are also the main producers and recipients of cargo so the inland transport network is relatively underdeveloped. Significant distances between the larger cities of North America demand long-distance transport corridors, so-called land bridges, which achieve dominance over other, shorter transport connections [15, slide 24].

The model was based on research methodology, joining the following methods:

- Review of both historical and contemporary literature concerning container terminals operations and their spatial configuration;

- Spatial analysis of both historical and contemporary container terminals' plans and configuration (including the distribution of logistics' objects co-operating with container terminals) based on cartographic material (plans, maps, and aerial photos) and study visits;

- Spatial analysis of urban network evolution in the light of W. Christaller central places theory;

- Analysis of cargo turnover and operation technologies of container terminals based on statistic data, professional literature, as well as study visits and interviews with terminals' employees.

The presented model was built on the basis of Rodrigue and Notteboom's [16, pp. 1929] and Wang and Decruet's [17] models. The spatial evolution of the container system has been the subject of many researchers' work. One of the first studies was created by Taaffe and others [18, p. 505] proving that the concentration of cargo in selected seaports (defined as the level of annual turnover) leads to the creation of priority corridors in the transport network of a hinterland. Based on the Taaffe's and others model [18] a five-stage Rimmer's model [19] was created, describing the development of ports along with the hinterland. In the 1980s Hayuth [20] introduced the concept of dominant ports and land load centers, which expansive development took place by gradually taking over the hinterlands of other ports. This phenomenon led to the concentration of cargo in a small number of strongly developed hub ports and monopolization of the main transport corridors. Barke [21], continuing Hayuth's considerations, additionally took into account the relocation of port functions to the undeveloped areas of port cities with efficient transport and communication links with the port. Van Klink [22] stated that the new role of the port was to take over logistic control over the inland network, and to integrate the work of spatially independent facilities. He also suggested enlarging the range of port logistics receipts in the subsequent phases of port development from the local scale (port city), through the regional one, to the macro scale (transport network). Van Klink [22] thus demonstrated the importance of the cooperation strategy between the port support entities and the inability to operate the port as an independent transport facility.

Fleming and Hayuth [23] and then Ducruet [24] supplemented the concept of "centrality" (the creation of gate-way ports being an access to hinterland) with the concept of "intermediacy". According to the concept of intermediacy, hinterland is spatially discontinuous (the logistics network is reduced to linear elements related with islands of inland distribution centers and transshipment/gate-way ports). Therefore the vast direct 
hinterland's market is no longer an indispensable factor in the concentration of large cargo streams.

Slack and Wang [25], Notteboom [26], Frémont and Soppé [27], Monios and Wilmsmeier [28] noticed the coexistence of cargo concentration trends in specific ports and cargo de-concentration in their hinterlands. As the next stage, following the phenomenon of cargo de-concentration in ports' hinterlands, Notteboom and Rodrigue [29] isolated the phase of regionalization. The existence of the regionalization phase was partly questioned by Rimmer and Comtois [30, p. 38], who considered it a continuation of the decentralization phase. Rodrigue and Notteboom [16, pp. 19-29] have synthesized previous models of the development of the port system and presented their own model, in which they distinguished six successive phases. Rodrigue and Nottebom [16, pp. 19-29] as well as Wang and Ducruet [17, pp. 58-69] referred to the model, indicating the last four phases of the model (two concentrations and two de-concentration) as those, that actually involve the evolution of the container system, recognizing the first two phases of Rodrigue and Notteboom model (2010) as the period of containerization experiments.

The six phases of the containerization process, mentioned in the Rodrigue and Notteboom model [16], of which the first four phases were described by Taaffe, Morrill and Gould [18], Hayuth [20], Barke [21], are therefore as follows:

1. an even distribution of ports and their hinterlands in the coastal space,

2. penetration and gradual capture of hinterlands by other ports,

3. formation of strong inland and sea connections (transport corridors) and gradual centralization (concentration of cargo mass in specific ports), which results in division of ports into hubs and feeder ports,

4. phase of full port centralization and creation of a hub-and-spoke service system,

5. phase of decentralization and appearance of large deep-water transit terminals in the foreland of ports (called: transshipment hubs, intermediate hubs, offshore hubs, gate-way terminals),

6. regionalization of both the foreground and the hinterland.

Since the concentration of cargo in a given container port occurs parallel with the spatial dispersion of functional elements of container terminals, with regard to the spatial evolution of the container system, it is not entirely accurate, that Rodrigue and Notteboom (2010, pp. 19-29) as well as Wang and Ducruet (2012, pp. 58-69) separate the phases of concentration and de-concentration from each other.

In reference to the above-described stages of the container system evolution (Figure 1), and on the basis of analysis of technologies used in container terminals, spatial layout and road-rail network serving terminals, four phases of spatial evolution of the European container system have been separated [3]. These phases are presented by the model (Fig. 2, Tab. 1) of the evolution of Europe's container system in terms of location theory:

- $\quad$ Phase 1 (1956-1970)

- almost every container terminal had both its direct ocean connections and feeder links

- in large terminals feeder connections from smaller terminals were concentrating

- the terminals had inland transport connections reaching the border of the region (up to $150 \mathrm{~km}$ ) and the distribution system of bigger cities (about $300 \mathrm{~km}$ ).

- $\quad$ Phase 2 (1970-1985/1988):

- concentration of cargo in selected ports has led to the creation of large hub-type container terminals

- the number of container terminals in the ports has increased - container multiterminal ports occurred

- ocean connections were existing almost exclusively in container hubs

- a line of transport links parallel to the shoreline has been created 
Phase 1 (1956-1970)

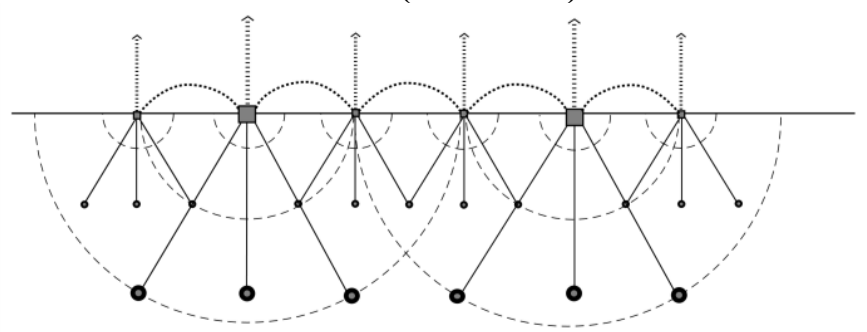

Phase 2 (1970-1985/1988)

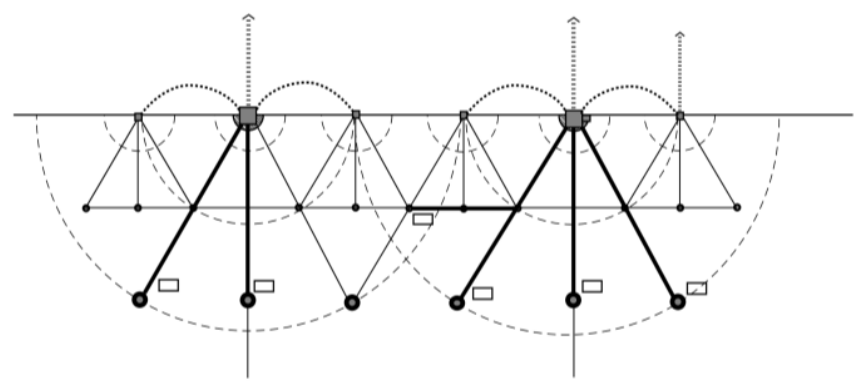

Phase 3 (1985/1988-2001/2003)

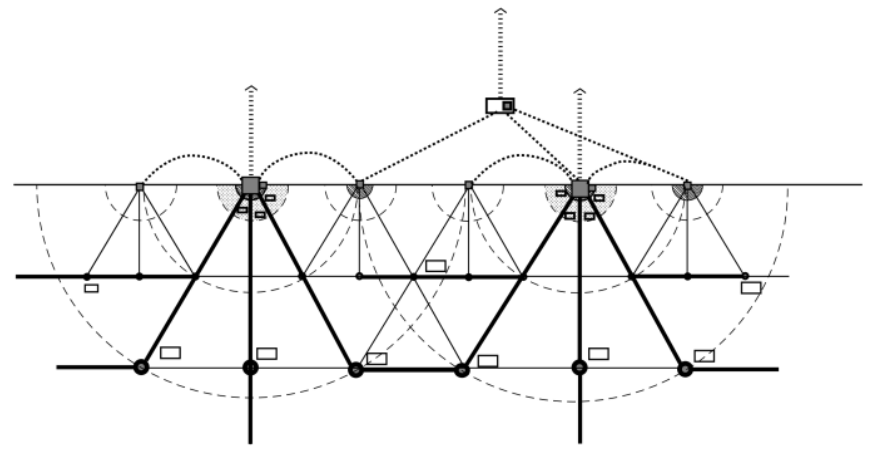

Phase 4 (2001/2003-)

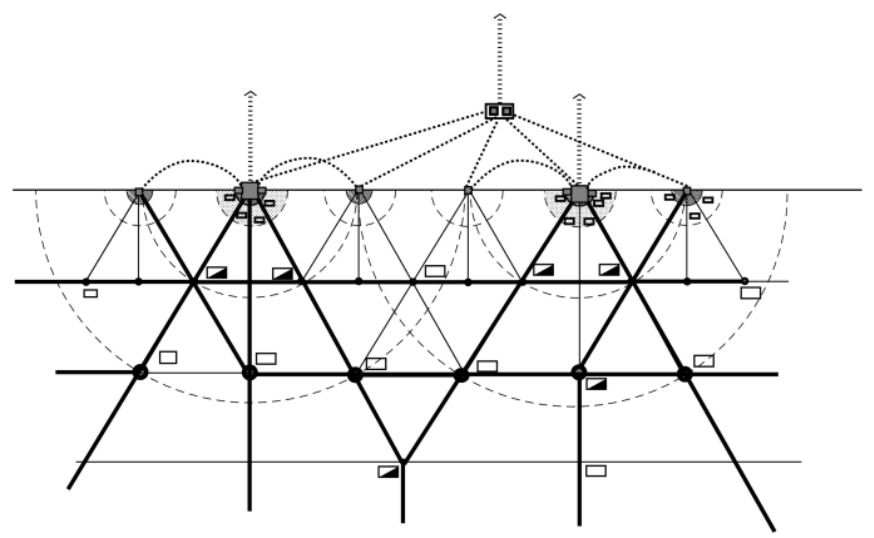

Fig. 2. A model of the evolution of the container system in Europe. Explanations at Table 1. [3, p. 73-75]. 
Table.1. Explanations to Fig. 2.

Nodes and objects:

- City

$\square \quad$ Container terminal
$\square \quad$ Gate-way terminal in foreland
$\square \quad$ Inland logistic centres

$\square$ Dry port

口 External objects associated with container terminals in the metropolitan zone (up to 50 $\mathrm{km})$

\section{Zones of hinterland:}

Direct (up to $5 \mathrm{~km}$ )

. 1 Metropolitan (up to $50 \mathrm{~km}$ )

\_, $\begin{aligned} & \text { - Regional (up to } 150 \mathrm{~km} \text { ) } \\ & \text { - Further hinterland (up to } 300 \mathrm{~km} \text { ) } \\ & \text { - Far hinterland (over } 500 \mathrm{~km} \text { ) }\end{aligned}$

Transportation connections

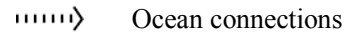

...... Feeder connections

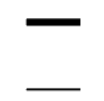

Inland transport corridors

Inland secondary connections

Source: [3, p. 73-75]

- the hinterlands of smaller container ports were captured by parallel transport connections and by the inland transport corridors of large terminals, which in result transformed smaller ports into feeder-oriented ones

- container terminals began to expand external functions in the area directly adjacent to them (up to $5 \mathrm{~km}$ )

- strong inland transport corridors have developed, which connected container hubs with their further hinterland in the further hinterland (about $300 \mathrm{~km}$ from the terminals), at the nodes of transport corridors and in vicinity of inland metropolises, the distribution and logistics centers of these cities were created, functionally connected with container sea container terminals.

- $\quad$ Phase 3 (1985/1988-2001/2003)

- in the crossings of shipping routes the gate-way terminals were established, concentrating cargo of many container terminals/ports in their foreland

- the largest ports have maintained ocean connections, while the rest served as terminals/feeder ports for hub or gate-way terminals

- big ports have built new deep-water container terminals of the third generation

- some of the functions were derived from container terminals outside (outsourced), into the area of the port city agglomeration (up to about $50 \mathrm{~km}$ )

- the inland transport corridors of larger container ports have been extended and strengthened (up to over $300 \mathrm{~km}$ )

- the network of logistic centers has expanded in the area of further facilities (150$300 \mathrm{~km})$.

- transport links parallel to the shore (also of the second line) have been established and strengthened, so in result the hinterlands of the larger container ports began to overlap.

- $\quad$ Phase 4 (2001/2003-)

- expansion of gate-way terminals on ports' forelands 
- concentration of cargo in hub ports, which in addition to direct ocean connections, have feeder connections to smaller ports/terminals and to gate-way ports

- erecting in larger container ports/terminals the new deep-water fourth generation automated terminals

- construction of dry ports in the previously not active zone of the port city region $(50-150 \mathrm{~km})$.

- construction of dry long-haul ports (in the area above $300 \mathrm{~km}$ )

- as a result of mutual capturing of ports' hinterlands, the extension, expansion and partial reorientation of the transport corridors in the hinterland takes place. The system of transport connection obtained the surface character, and enabled flexible route selection (synchro-modal transportation).

The last phase (Figure 2, phase 4) of the development of the container system consists in networking of the cargo flow, and in the reorganization of hinterlands' coverage ranges of individual container ports. It can therefore be considered as an activity that at least theoretically equalizes the development opportunities of container ports by unifying transport accessibility from these ports to the hinterland. In practice, however, it leads to the expansion of the hinterland of these container ports, which have the most extensive system of functional arms in the hinterland. In this situation, one should agree with van Klink [31, 22], that currently the port has lost an ability to function as an independent transport hub. The new task of port management (or container terminal operators) has therefore become to control the availability of the land network and to integrate the work of spatially independent logistic facilities in the hinterland. Such an approach requires close cooperation of port authorities and terminals, both with the transport and logistics entities in the hinterland, as well as with the territorial self-governments leading their spatial policy.

Spatial de-concentration of container terminals consisting in the construction of their "booms" should be considered as a method of strengthening the position of a given container port and its functional area, and an attempt to concentrate the cargo on its main area. Concentration of cargo within a given supply chain is accompanied by spatial deconcentration of objects related to the flow of containers through this chain. This approach to the issue explains why Ducruet et al. [32, p. 359] ascribe the causes of spatial concentration to the agglomeration's activities, while the basis of the process of deconcentration is seen as the operation of global forces.

Christaller's communication principle (Ger. Verkhersprinzip) says that the most favorable location for settlement centers occurs when the largest number of towns in the cheapest way is communicated with the most important centers [33, pp. 63-64]. Hence, it can be concluded that the phenomenon of gradual transformation of polycentric settlement systems into node-band systems is a natural consequence of this principle.

In the theory of Christaller [33] and Lösch [34] the grid of the central centers system was determined by determining the temporal availability assuming a homogeneous, isotropic space, where the range assigning the area to the center was 21 and $36 \mathrm{~km}$ (one-day pedestrian/horse accessibility). The shape of Christller's hexagonal mesh [33, pp. 63-64] should still be treated as an extremely efficient transport solution with a very favorable structure index [35, pp. 34-35]. But modern technological possibilities and the real speed of transport (lorries, railways) have meant that temporary accessibility from large port cities should now be designated for other zones than was the case in the original theory. The coverage of these zones is determined by the actual accessibility of the car: within 1 hour $(50 \mathrm{~km}), 4-6$ hours - round trip within 1 day (approximately $300 \mathrm{~km}$ ) and 1 day (over 500 $\mathrm{km})$. The region of the port city of $150 \mathrm{~km}$ (1.5-2 hours of travel) should also be taken into account, where there are strong functional links with the central region of the region. These zones also have their fixation in the location of cities in the hinterland - the first line of 
cities are medium-sized cities located within a radius of $150 \mathrm{~km}$ from the port city, the next line is larger cities located within $300 \mathrm{~km}$ of the port cities.

In fact, the regular grid of accessibility is distorted by the resistance of a heterogeneous space [36, p. 185]. In the case of gate-way cities [37, pp. 269-285], the network significantly disturbs the course of far-reaching transport corridors. Therefore, Christaller's theory should be supplemented with the theory of system-network theory, developed by Hohenberg and Hollen-Lees [38]. It refers to the open (not self-sufficient) and anisotropic space and assumes that the settlement structure is a system of nodes (vertices), whose hierarchy develops mainly through the transport system and far-reaching contacts and interactions. Therefore, the regular Christaller's hexagon in the case of harbor metropolis is disproportionately stretched along the main transport routes leading to the back of the port city. The theory of network-systems indicates, that the role played by port cities in the settlement structure depends on the nature of transport infrastructure (i.e. the system of highways, railway lines, inland waterway connections, reloading and distribution and logistics centers).

Analysis of the spatial development of the container system authorizes the thesis, that the reorganization of container ports is one of the signs of their adaptation to the dynamically transforming hierarchical settlement system [33] into a mesh of an order of magnitude higher than the previous one - in the arrangement of metropolitan connections. As is known, the organization of the settlement structure is, as a rule, hierarchical, which results from the principle of concentration and accessibility of areas [2, p. 14]. The high cost of building the transport infrastructure means, that communication links are first established for the most important locations [2, pp. 14-15]. Therefore, the market areas of the centers are also hierarchical [36, p. 198], e.g. container ports facilities. What's more, Christaller [33, p. 15] pointed to the fact, that central places do not have to be cities at all, although they are intuitively associated with such a concentration [39, pp. 14-16], [40, p. 30]. Therefore, large complexes of logistic and distribution buildings, i.e. large dry ports located in strategic nodes of the transport network, could also be considered as central places so understood. Along with the expansion of transport corridors, perpendicular to the shoreline, corridors parallel to the shore are gradually being built, and transshipment centers are developed at the intersection of both directions, what leads to deepening and widening the range of hinterlands of selected container ports.

\section{Conclusions}

Concentration of cargo in a given port is accompanied by the development of a network of external facilities at the near and further hinterland of the container terminal (this phenomenon is called "Standortspaltung" by Schätzl [41]) to increase the retention of the hinterland and to increase the cargo flow through the terminal. Output of subsequent functions beyond the basic outline of the terminal (spatial de-concentration of container terminals) takes place respectively: in neighboring areas and in the distant hinterland, in the area of the port metropolis, in the port city region, and in its distant hinterland.

The effect of progressing globalization is the integration of the land and sea subsystems of each from container ports into one coherent (so-called seamless) supply chain, in which the flow of cargo and information is fast, fluent and highly automated. Currently, the process of integration of logistics chains of individual container ports into one global delivery system is underway, based on synchro-modal transport (flexible choice of route and mode of transport in real time). This process changes the current understanding of the concept of port's hinterland (the hinterland is no longer continuous), and remodel the previous hierarchy (structure of connections) of individual port and land agglomerations (metropolises), and thus the entire settlement structure. At the same time, the reorganization 
of the container system is also partly the result of the dynamic transformation of the settlement system. Modern possibilities of movement and the associated cardinal change in the temporal accessibility of the areas caused that the cell of the settlement structure increased by an order of magnitude in relation to the canvas of the original theory of central places [33]. From the point of view of transport, the main layout of the settlement system is currently a network of metropolitan connections with a radius of around $300 \mathrm{~km}$. The port's metropolises, as gate-way cities [37], according to system-network theory [38], have a distorted netting, extending along the main transport corridors leading to the hinterland. In addition, according to the Christallerian communication principle [33], polycentric settlement structures are gradually transforming into node-band systems.

\section{References}

[1] UNCTAD (eds), Development and improvement of ports. The principles of modern management and organization (TD/B/C.4/AC.7/13), pp. 1-80 (1992)

[2] J.-P. Rodrigue, C. Comotois, B. Slack, The Geography of transport systems, 2 ed., Routledge Taylor and Francis Group, London-New York, pp. 1-352 (2009)

[3] K. A. Krośnicka, Przestrzenne aspekty kształtowania i rozwoju morskich terminali kontenerowych, Wydawnictwo Politechniki Gdańskiej, Gdańsk, ISBN 978-83-7348-684-3, pp. 1-233 (2016)

[4] Z. Krasucki, J. Neider, Konteneryzacja w transporcie międzynarodowym, PWN, Warszawa, pp. 1-131.

[5] A Ashar., 2002, Revolution Now, Containerization International, January, pp. 56-59 (1986)

[6] J. Lu, Z. Chang, The Construction of Seamless Supply Chain Networks: The

Development of dry Ports in China, [in:] Bergqvist R., Wilmsmeier G., Cullinane K. (eds), Dry Ports - A Global Perspective. Challenges and Developments in Serving Hinterlands, Ashgate Publishing, Routledge, pp. 155-172 (2013)

[7] J. Monios, A functional analysis of dry port systems: the case of Spain, presentation at the Conference on Intermodal Strategies for Integrating Ports \& Hinterland, Edinburgh (2010)

[8] J. Robinson, Global and world cities: a view from off the map, International Journal of Urban and Regional Research, 26(3), pp. 531-554 (2002)

[9] S.-H. Woo, S.J. Pettit, A.K.C Beresford, Port evolution and performance in changing logistics environments, Maritime Economics \& Logistics, 13(3), pp. 250-277 (2011)

[10] J. Lu, Z. Chang, The Construction of Seamless Supply Chain Networks: The Development of dry Ports in China, [in:] Bergqvist R., Wilmsmeier G., Cullinane K. (eds), Dry Ports - A Global Perspective. Challengesand Developments in Serving Hinterlands, Ashgate Publishing, Routledge, pp. 155-172 (2013)

[11] J.G de Gijt, M.L. Broeken (eds), Handbook Quay Walls, Balkema - Proceedings and Monographs in Engineering, Water and Earth Sciences, CRC Press, pp. 1-718 (2005) [12] T. Notteboom, J.-P. Rodrigue, Port regionalization: towards a new phase in port development, Maritime Policy and Management, 32(3), pp. 297-313 (2005)

[13] V. Roso, J. Woxenius, K. Lumsden, The dry port concept: connecting container seaports with the hinterland, Journal of Transport Geography, 17(5), pp. 338-345 (2009)

[14] J. Monios, G. Wilmsmeier, Giving a direction to port regionalization, Transportation Research Part A, 46(10), pp. 1551-1561 (2012)

[15] J.-P. Rodrigue, T. Notteboom, The Future of Containerization: Box Logistics in Light of Global Supply Chains, conference presentation, IAME, Greece, July 2007, pp. 1-25 (2007) [16] J-P. Rodrigue, T. Notteboom, Foreland based regionalization: Integrating intermediate hubs with port hinterlands, Reaserch in Transport Economics, 27(1), pp. 19-29 (2010) 
[17] C. Wang, C. Ducruet, New port development and global city making: emergence of the Shanghai-Yangshan mulilayered gateway hub, Journal of Transport Geography, 25, pp. 5869 (2012)

[18] E.J. Taaffe, R.L. Morrill, P.R. Gould, Transport expansion in undeveloped countries, Geographical Review, 53(4), pp. 503-529 (1963)

[19] P.J. Rimmer, The search for spatial regularities in the development of Australian seaports 1861-1961/62, Geografiska Annaler, 49(1), pp. 42-54 (1967)

[20] Y. Hayuth, Containerisation and the load center concept, Economic Geography, 57(2), pp. 160-176 (1981)

[21] M. Barke, Transport and trade, Oliver \& Boyd, Edinburgh, pp. 1-249 (1986)

[22] H.A. Klink van, The port network as a new stage in port development: the case of Rotterdam, Environment and Planning A, 30(1), pp. 143-160 (1998)

[23] D.K. Fleming, Y. Hayuth, Spatial characteristics of transportation hubs: centrality and intermediacy, Journal of Transport Geography, 2(1), pp. 3-18 (1994)

[24] C. Ducruet, Port city relationships In Europe and Asia, Journal of International Logistics and Trade, 4(2), pp. 13-35 (2006)

[25] B. Slack, J.J. Wang, The challenge of peripheral ports: an Asian perspective, GeoJournal, 56(2), pp. 159-166 (2002)

[26] T. Notteboom, The peripheral port challenge in container port systems, [in:] Leggate $\mathrm{H}$., McConville J., Morvillo A., International maritime transport: perspectives, Routledge, pp. 173-188 (2005)

[27] A. Frémont, M. Soppé, Northern European range: shipping line concentration and port hierarchy, [in:] J. Wang, T. Notteboom, D. Olivier, B. Slack (eds), Ports, cities, and global supply chains, Ashgate, Alderschot, pp. 105-120 (2007)

[28] J. Monios, G. Wilmsmeier, The role of intermodal transport in port regionalization, Transport Policy 30, pp. 161-172 (2013)

[29] T. Notteboom, J.-P. Rodrigue, Port regionalization: towards a new phase in port development, Maritime Policy and Management, 32(3), pp. 297-313 (2005)

[30] P.J. Rimmer, C. Comtois, China's container-related dynamics, 1990-2005, GeoJournal, 74(1), pp. 33-50 (2009)

[31] H.A. Klink van, Creating port networks: the case of Rotterdam and the Baltic region, International Journal of Transport Economics, 14(3), pp. 393-409 (1997)

[32] C. Ducruet, S. Roussin, J.C. Jo, Going West? Spatial polarization of the North Korean port system, Journal of Transport Geography, 17(5), pp. 357-368 (2009)

[33] Christaller W., Die Zentralen Orte in Süddeutschland. Eine ökonomisch-

geographische Untersuchung über die Gesetzmässigkeit der Vorbereitung und Entwicklung der Siedlungen mit städtischen Funktionen, Jena, pp. 1-340 (1933)

[34] Lösch A., Gospodarka przestrzenna - teoria lokalizacji, PWE Warszawa (oryginał:

Lösch A., Economics of Location, New Haven 1954), pp. 1-407 (1963)

[35] W. Ratajczak, Analiza i modele wpływu czynników społeczno-gospodarczych na kształtowanie sieci trans-portowej, PWN Warszawa-Poznań, pp. 1-140 (1980)

[36] P. Śleszyński, Dostępność czasowa i jej zastosowania, Przegląd Geograficzny, 86(2), pp. 171-215 (2014)

[37] A.F. Burghardt, A hypothesis about gateway cities, Annals of the Association of American Geographers, 61 (2), pp. 269-285 (1971)

[38] P.M. Hohenberg, L.H. Lees, The making of urban Europe, 1000-1950, Harvard University Press, pp. 1-398 (1985)

[39] E. Nowosielska, Teoria Christallera - prawda i mity (w sprawie nieporozumień pojęciowych), Dokumentacja Geograficzna 3, pp. 1-83 (1992) 
[40] E. Siemianowska, O zastosowaniu niektórych modeli teoretycznych w badaniach nad ośrodkami miejskimi w średniowieczu, Archaeologia Historica Polona 22, pp. 27-54 (2014)

[41] L. Schätzl, Wirtschaftsgeographie 1 - Theorie, 6th Edition, UTB, Paderborn, pp. 1280 (1996) 